\title{
QUALITY PARAMETERS AND NUTRITIVE VALUE OF WILD AND CULTURED NILE TILAPIA SOLD IN ASSIUT CITY, EGYPT
}

\author{
SHERIEF M.S. ABD-ALLAH and HESHAM A.A. ISMAIL \\ Department of Food Hygiene (Meat Hygiene), Faculty of Veterinary Medicine, Assiut University, Egypt
}

Received: 26 September 2016; Accepted: October 2016

\begin{abstract}
Fish have always been considered to be an excellent source of protein, minerals and a low-fat product. The present study was carried out to evaluate the sensory, chemical and bacterial quality as well as proximate chemical composition of the wild Nile tilapia in comparison with the cultured one available in Assiut fish-sale markets. A total of 99 (50 wild and 49 cultured) samples of fresh Nile tilapia fish were randomly collected from different fish-sale markets in Assiut city. Sensory evaluation revealed that all of the wild and cultured tilapia samples were organoleptically accepted. The mean sensory score value of the cultured samples was significantly $(\mathrm{P}<0.05)$ higher than that of the wild. The $\mathrm{pH}$, total volatile bases "TVB" (mg N/100g fish flesh) and thiobarbituric acid "TBA" (mg malonaldehyde/kg fish flesh) mean values were 6.81 $\pm 0.03,17.81 \pm 0.5$ and $1.84 \pm 0.17$ in wild tilapia and $6.79 \pm 0.02,21.38 \pm 0.63$ and $1.02 \pm 0.08$ in cultured tilapia, respectively. The incidence of coliforms, fecal coliforms, $E$. coli and $C l$. perfringenes in wild tilapia samples was $88,34,0$ and $0 \%$, while in cultured samples it was 83.67, 40.82, 2.02 and $6.12 \%$, respectively. The results of proximate chemical composition percentages revealed that the mean values of moisture, protein, fat, ash and carbohydrate were significantly $(\mathrm{P}<0.05)$ different in wild than in cultured tilapia. The calculated gross energy mean value (Kcal/100g fish flesh) was higher in cultured $(100.73 \pm 1.44)$ than in wild $(83.29 \pm 0.06)$ tilapia with a significant $(\mathrm{P}<0.05)$ difference between them. From the obtained results it could be concluded that from the quality point of view wild Nile tilapia is better than the cultured one.
\end{abstract}

Key Words: Tilapia, Wild, Cultured, Quality, Composition, Sensory, Chemical, Bacterial.

\section{INTRODUCTION}

Fish is a good source of the vitamins which required by human being, contains a good selection of minerals, and its protein compares favorably with that provided by meat, milk and eggs (FAO, 2001).

Commercial fresh-water fish culture started in Egypt in 1961, with a small contribution to fish production. In recent years, it contributes a large proportion (about $65 \%$ ) of the total production which increased from 45000 ton per year in the mid 1980 to 705490 ton per year in 2009 to compensate the shortage in red meat production (GAFRD, 2010). Some Egyptian people use fish as the only source of animal protein throughout the year.

Nile tilapia is a fresh-water fish species, has been known as one of the most widely cultured species due to its fast growth rate and easy cultivation. It can tolerate a wide range of environmental conditions, able to reproduce in captivity, feed on low trophic levels and has good sensorial flesh properties (Boari et al., 2008 and Dergal et al., 2013).

Corresponding author: Dr. HESHAM A.A. ISMAIL

E-mail address: Sherief74@yahoo.com

Present address: Department of Food Hygiene (Meat Hygiene),

Faculty of Veterinary Medicine, Assiut University, Egypt.
Fish "quality" has been assessed using various parameters including: texture, color, fat content, fatty and amino acids composition, mineral content, microbiological count and others (Haard, 1992; Rasmussen, 2001 and Jankowska et al., 2003).

In sensory analysis; appearance, odor, flavor and texture are evaluated using the human senses. Flavor and other quality aspects of cultured fish may reduce consumer appeal when the cultured varieties are compared to their wild counterparts; farmed fish are known to express off-flavors (FAO, 1995 and Gonzalez et al., 2006).

The ultimate $\mathrm{pH}$ of fish flesh after death is related to the amount of available glycogen. The more glycogen present, the lower the $\mathrm{pH}$ of the fish flesh which improves the keeping quality (Hall, 1992). The $\mathrm{pH}$ determinations have been applied to assess the degree of quality deterioration as $\mathrm{pH}$ increases due to the production of ammonia and amines by microbial and tissue enzymes activity during storage (National Academy of Sciences, 1985).

Total volatile basic amines (TVB) include the measurement of trimethylamine, dimethylamine, ammonia and other volatile basic nitrogenous compounds associated with seafood spoilage. It is one of the most widely used measurements of seafood 
quality, where its significant increase indicates fish deterioration (FAO, 1995; Yao et al., 2009 and Noseda et al., 2010).

Fish lipids have high content of polyunsaturated fatty acids (PUFA), being very susceptible to oxidation. Some of the secondary oxidation products, aldehydes, have very unpleasant odors and flavors, responsible for the fishy and rancid character associated with spoiled fish. Thiobarbituric acid-reactive substances (TBA-RS), an aldehydic secondary oxidation products (FAO, 1995 and Ozogul et al., 2011) were reported to show some correlation between its level and fish quality (Hoyland and Taylor, 1991; Raharjo and Sofos, 1993; Yarnpakdee et al., 2012).

The fish flesh which is generally sterile immediately after catching, may get contaminated with different micro-organisms during subsequent handling, as these can penetrate from skin and gut to the flesh (Brock et al., 1984 and Etzel et al., 1998). Fish may be subjected to microbial contamination either during their presence in aquatic environment or after being harvested for marketing, where environmental conditions usually affect the growth and multiplication of such micro-organisms (FAO, 2012 and Amer et al., 2012). The presence of coliforms indicates a potable fecal source of contamination, and their presence in great number may raise the public health hazard (National Academy of Sciences, 1985). As well, Clostridium perfringens spores can reach fish in their water habitat (particularly near sewage outfalls) or during handling. Numbers greater than $10^{6}$ are necessary to cause illness. Such quantities do not reach foods by mere contamination, but accumulate as a result of multiplication of vegetative cells (Bryan, 1980).

Wild and cultured fish differed in nutrients (Nettleton and Exler, 1992), sensorial, chemical and physical properties (Cox and Karahadian, 1998; Grigorakis et al., 2003; Delwiche and Liggett, 2004). Diet availability is one of the major factors affected fish body composition (Lie, 2001; Alasalvar et al., 2002; Ashraf et al., 2011). In wild fish, the composition was strongly influenced by the environmental conditions which determined the nutrients availability (Izquierdo et al., 2003), while in cultured fish, the feeding with artificial diets supplemented a wide range of nutrients and determined the flesh composition (Periago et al., 2005). The study of chemical composition of fish is of interest for the processor, nutritionist, cook and consumer as it influences both keeping quality and technological characteristics of the fish (Huss, 1988; FAO, 2001).

The increased production of cultured Nile tilapia has raised concerns over its quality in comparison with wild one. As consumers now are more aware of possible food hazards and have more demand in respect of freshness, naturalness, and microbial safety, so there is a need to access the quality, safety and nutritional value of fish and in particular cultured one.

For that, the main objective of this study was to shed light on the freshness, chemical and bacterial quality and proximate compositions of cultured and wild Nile tilapia fish, in order to provide information that guide consumers during selection between them under native conditions of Assiut city, Egypt.

\section{MATERIALS AND METHODS}

A total of 99 (50 wild and 49 cultured) samples of fresh Nile tilapia fish were randomly collected from different fish-sale markets in Assiut city, Egypt. The samples transported directly to the laboratory, being kept at $4^{\circ} \mathrm{C}$ till being examined with a minimum of delay. At the laboratory, each sample was examined sensorily then was prepared for bacteriological and chemical examinations.

For bacteriological examination, the scales were removed by sterile instruments and the flesh with the skin intact collected in a sterile mortar. For chemical analysis, flesh without skin was collected in a clean mortar. Each part of the sample was then mixed thoroughly being ready for examinations. Prepared samples not subjected to direct analysis were kept at $20^{\circ} \mathrm{C}$ till being analyzed.

\section{1) Sensory evaluation}

The appearance of the skin, eyes, gills, flesh (cut from abdomen), color (along vertebral column), and organs; condition of the flesh, vertebral column, and peritoneum; as well as smell of gills, skin and abdominal cavity were evaluated by members of The Food Hygiene Department (Meat Hygiene) according to FAO (1995). Ten characteristics were scored on a scale from 3 to 0 . A mean score was obtained by dividing the scores summation by the number of the evaluated characteristics. Scores of greater than 2.7 are graded "E", from 2.0 - 2.7 graded "A", from $1.0-2.0$ graded "B", and less than 1.0 graded "C" (un-official score; fish discarded for human consumption) (Hall, 1992).

2) Chemical analysis

\subsection{Chemical quality parameters}

a) Determination of $\mathbf{p H}$

The $\mathrm{pH}$ of the fish flesh was determined according to Lyhs et al. (1998) using pH-Meter (lovibond, SD50).

b) Determination of total volatile bases (TVB) The TVB was determined according to Pearson (1976) using macro-kjeldahl apparatus.

TVB "mg N/100g fish flesh" = (Titration Blank) x 14

c) Determination of thiobarbituric acid (TBA) (mg malonaldehyde/kg flesh) 
Oxidative rancidity of the fish was determined by measuring the thiobarbituric acid-reactive substances (TBA-RS) according to Buege and Aust (1978).

\subsection{Chemical composition}

The determination of moisture, fat, crude protein, and ash contents of the samples, as well as calculation of the total carbohydrate was done according to AOAC (2000).

a) Determination of moisture content

The free water content of the flesh was determined using hot air oven (Fine Tech, Korea) Moisture $\%=$ Weight lost $\times 100$

$$
\text { Sample weight }
$$

\section{b) Determination of fat content}

Fat percentage of the sample was determined using ether extract (Soxhlet) method with a slight modification. Briefly, 1 gm (dry weight) of each sample was weighted onto filter paper of known weight, wrapped and extracted with petroleum ether (60/80) in the Soxhlet apparatus for 16-18 hrs. The extracted samples was then dried overnight in hot air oven at $65^{\circ} \mathrm{C}$, transferred to desiccator and left to cool, then weighted. The loss in weight was used to calculate the fat percentage.

Fat $\%=\frac{\text { Weight lost }}{\text { Sample weight }} \times 100$

\section{c) Determination of crude protein content}

Macro-Kjeldahl method was used to determine the total nitrogen percentage of the sample. From the dried sample $0.5 \mathrm{gm}$ was used for digestion. Crude protein $\%=$ Total nitrogen $\times 6.25$

\section{d) Determination of ash content}

One gram (dry weight) of the sample was ashed using the muffle furnace (Thermolyne, USA).

Ash $\%=$ Weight of the ash $\times 100$

$$
\text { Sample weight }
$$

N.B.: All estimations on the dry weight were converted to the wet weight basis using the following equation according to Jurgens and Bregendahl (2007) before being used in the subsequent calculations.

Nutrient wet basis $\%=$ Nutrient dry basis $\% \mathrm{x}$ Dry matter \%

e) Calculation of the total carbohydrate content The carbohydrate percentage was calculated by subtraction using the wet weight basis of the content.

Total carbohydrate $\%=100-($ moisture $\%+$ protein $\%+$ fat $\%+$ ash $\%)$.

\section{f) Calculation of the gross energy value}

According to Merrill and Watt (1973) the gross energy value per $100 \mathrm{gm}$ of fish flesh was calculated using the following equation:

Gross energy value $(\mathrm{Kcal} / 100 \mathrm{~g})=($ protein $\% \mathrm{x}$ $4)+($ fat $\% \times 9)+($ carbohydrate $\% \times 4)$.

\section{3) Bacteriological estimation}

\subsection{Preparation of samples}

Under aseptic conditions, 10 grams of each sample were removed and transferred into sterile plastic bag, and then $90 \mathrm{ml}$ of $0.1 \%$ sterile peptone water was added. The contents were homogenized for $2 \mathrm{~min}$ in the stomacher (Seward 400). Ten fold serial dilutions were prepared using sterile $0.1 \%$ peptone water.

N.B.: Three tubes dilutions method was used to calculate coliforms, fecal coliforms and E. coli most probable number (MPN) count according to AOAC (1980)

\subsection{Coliforms count (MPN/g)}

Laury sulphate broth (Oxoid, CM0451) was used as inoculation medium for presumptive enumeration of coliforms, while brilliant green bile $(2 \%)$ broth (Himedia, M121) was used for confirmatory enumeration

\subsection{Fecal coliforms count (MPN/g)}

EC medium (Lab Media, LAB171) was used for the count being incubated in water bath at $45 \pm 0.5^{\circ} \mathrm{C}$.

\subsection{E. coli count $(\mathrm{MPN} / \mathrm{g})$}

Eosin methylene blue "EMB" agar (Oxoid, CM69) was used for inoculation. Typical colonies are nucleated (dark center) with metallic sheen.

\subsection{Enumeration of Clostridium perfringens} (MPN/g)

Lactose sulfite broth (Biolife, ref 4015792) was used for inoculation according to Beerens et al. (1980), being incubated at $46 \pm 0.5^{\circ} \mathrm{C}$.

\section{RESULTS}

Sensory evaluation of the wild tilapia samples revealed that $41(82 \%)$ and $9(18 \%)$ of them were of grades "A" and "B", respectively. For cultured tilapia, $30(61.22 \%)$ samples were of grade "E" while, 19 $(38.78 \%)$ were of grade "A" as shown in Table 1. The minimum, maximum and mean values for wild tilapia sensory evaluation were $1.59,2.5,2.17 \pm 0.03$, respectively, while for cultured tilapia were 2.1, 2.8, and $2.72 \pm 0.02$, respectively. The sensory score mean value for the cultured tilapia was significantly $(\mathrm{P}<0.05)$ higher than in the wild (Table 2, 4, 6 and Figure 1).

Concerning chemical quality parameters, the minimum, maximum and mean values for $\mathrm{pH}$, TVBN and TBA in wild tilapia were 6.41, 7.52 and $6.81 \pm 0.03 ; 11.2,25.2$ and $17.81 \pm 0.5 \mathrm{mg} \mathrm{N} / 100 \mathrm{~g}$ fish flesh; and $0.19,5.43$ and $1.84 \pm 0.17 \mathrm{ppm}$, respectively (Table 2). In case of cultured tilapia the previously mentioned values were $6.41,7.08$ and $6.79 \pm 0.02 ; 14$, $28,21.38 \pm 0.63 \mathrm{mg} \mathrm{N} / 100 \mathrm{~g}$ flesh; and $0.04,3.1$ and $1.02 \pm 0.08 \mathrm{ppm}$, respectively (Table, 4 ). There was no significant difference between wild and cultured tilapia for mean value of $\mathrm{pH}$. For TVBN mean value, it was significantly $(\mathrm{P}<0.05)$ higher in cultured 
tilapia, while for TBA mean value, it was significantly $(\mathrm{p}<0.05)$ higher in wild than in cultured tilapia (Table 6 and Figure 1).

Regarding bacterial quality parameters, the data recorded in Table 3 show that 44 (88\%) and 17 (34\%) of the 50 examined wild tilapia samples were positive for coliforms and fecal coliforms count, respectively. However, none of the examined samples was positive for the $\mathrm{E}$. coli or $\mathrm{Cl}$. perfringenes count. The minimum, maximum and median values for coliforms were 3.6, 1100 and $9.1 \mathrm{MPN} / \mathrm{g}$, respectively, while for fecal coliforms were 3, 150 and $9.1 \mathrm{MPN} / \mathrm{g}$, respectively. In case of cultured tilapia, 41 (83.67\%), $20(40.82 \%)$ and $3(6.12 \%)$ out of the 49 examined samples were positive for coliforms, fecal coliforms and $\mathrm{Cl}$. perfringenes count, respectively. The minimum, maximum and median values for the previously mentioned bacteria were $2.3,>1100$ and 26; 3, 1100 and 9.1; and 7.3, 43 and 9.1 MPN/g, respectively. Only one sample was positive for $E$. coli with a count of $3.6 \mathrm{MPN} / \mathrm{g}$ (Table, 5).

The results of chemical composition analysis revealed that the moisturepercentage in wild tilapia ranged from 77.86 to $82.15 \%$ with a mean value of
$79.63 \pm 0.13$. For protein, fat and ash the values ranged from 14.78 to $19.41,0.41$ to 2.16 , and from 0.85 to $1.22 \%$ with mean values of $17.5 \pm 0.12,1.2 \pm 0.05$, and $1.04 \pm 0.01$, respectively. Calculated carbohydrate percentage ranged from 0.04 to 1.26 , with a mean of $0.63 \pm 0.06$ (Table, 7 ). With respect to cultured tilapia, the data registered in Table 8 declare that the moisture, protein, fat and ash percentages ranged from 73.74 to $80.38,15.27$ to $19.63,1.2$ to 4.9 , and from 0.89 to $1.45 \%$ with mean values of $77.17 \pm 0.22$, $17.91 \pm 0.15,2.82 \pm 0.13$, and $1.17 \pm 0.02$, respectively. The calculated carbohydrate showed a minimum of $0.1 \%$, a maximum of $1.94 \%$ and a mean value of $0.94 \pm 0.07$. The mean value for moisture was significantly $(\mathrm{P}<0.05)$ higher in wild tilapia; while those of protein, fat, ash and calculated carbohydrate were significantly $(\mathrm{P}<0.05)$ higher in cultured tilapia (Table 9).

As recorded in Table 10 the calculated gross energy values (Kcal/100g fish flesh) ranged from 73.75 to 92.51 in wild tilapia with a mean value of $83.29 \pm 0.06$ and from 85.2 to 124.77 in cultured tilapia with a mean value of $100.73 \pm 1.44$, which is significantly $(\mathrm{P}<0.05)$ higher than in wild tilapia.

Table 1: Sensory grading of wild and cultured Nile Tilapia

\begin{tabular}{ccccc}
\hline \multirow{2}{*}{ Grades } & \multicolumn{2}{c}{ Wild tilapia $(\mathrm{n}=50)$} & \multicolumn{2}{c}{ Cultured tilapia $(\mathrm{n}=49)$} \\
\cline { 2 - 5 } & Number & \% & Number & \% \\
\hline E & - & - & 30 & 61.22 \\
\hline A & 41 & 18 & 19 & - \\
\hline B & 9 & - & - & - \\
\hline C & - &
\end{tabular}

Grade E: > 2.7; Grade A: 2-2.7; Grade B: 1-2; Grade C: <1

Table 2: Sensory and chemical quality parameters of wild Nile Tilapia $(n=50)$

\begin{tabular}{lcccc}
\hline \multicolumn{1}{c}{ Parameter } & Min & Max & Mean & 土SE \\
\hline Sensory & 1.59 & 2.5 & 2.17 & \pm 0.03 \\
\hline pH & 6.41 & 7.52 & 6.81 & \pm 0.03 \\
\hline TVBN (mg/100g flesh)* & 11.2 & 25.2 & 17.81 & \pm 0.5 \\
\hline TBA (mg/kg) & 0.19 & 5.43 & 1.84 & \pm 0.17 \\
\hline
\end{tabular}

$* n=41$; the other 9 samples size was not enough for the TVN determination

Table 3: Bacterial quality parameters of wild Nile Tilapia $(n=50)$

\begin{tabular}{|c|c|c|c|c|c|}
\hline \multirow{2}{*}{ Parameter } & \multicolumn{2}{|c|}{ Positive samples } & \multirow{2}{*}{ Min } & \multirow{2}{*}{ Max } & \multirow{2}{*}{ Median } \\
\hline & No & $\%$ & & & \\
\hline Coliform count (MPN/g)* & 44 & 88 & 3.6 & 1100 & 9.1 \\
\hline Fecal coliform count (MPN/g) & 17 & 34 & 3 & 150 & 9.1 \\
\hline E. coli count (MPN/g) & - & - & - & - & - \\
\hline Cl. perfringenes count (MPN/g) & - & - & - & - & - \\
\hline
\end{tabular}

*The confirmatory count 
Table 4: Sensory and chemical quality parameters of cultured Nile Tilapia $(n=49)$

\begin{tabular}{|c|c|c|c|c|}
\hline Parameter & Min & $\operatorname{Max}$ & Mean & $\pm \mathrm{SE}$ \\
\hline Sensory & 2.1 & 2.8 & 2.72 & \pm 0.02 \\
\hline pH & 6.41 & 7.08 & 6.79 & \pm 0.02 \\
\hline TVBN (mg/100g flesh)* & 14 & 28 & 21.38 & \pm 0.63 \\
\hline TBA (mg/kg) & 0.04 & 3.1 & 1.02 & \pm 0.08 \\
\hline
\end{tabular}

$*_{n}=41$; the other 8 samples size was not enough for the TVN determination

Table 5: Bacterial quality parameters of cultured Nile Tilapia $(n=49)$

\begin{tabular}{lcccccc}
\hline \multirow{2}{*}{ Parameter } & \multicolumn{2}{c}{ Positive samples } & & Min & Max & Median \\
\cline { 2 - 5 } & No & $\%$ & & & \\
\hline Coliform count (MPN/g)* & 41 & 83.67 & 2.3 & 1100 & 26 \\
\hline Fecal coliform count (MPN/g) & 20 & 40.82 & 3 & 1100 & 9.1 \\
\hline E. coli count (MPN/g) & 1 & 2.02 & 3.6 & - & - \\
\hline Cl. perfringenes count (MPN/g) & 3 & 6.12 & 7.3 & 43 & 9.1 \\
\hline
\end{tabular}

*The confirmatory count

Table 6: Mean values of sensory and chemical quality parameters of wild and cultured Nile Tilapia

\begin{tabular}{lcc}
\hline \multicolumn{1}{c}{ Parameters } & Wild tilapia & Cultured tilapia \\
\hline Sensory & $2.16^{\mathbf{b}}$ & $2.72^{\mathbf{a}}$ \\
\hline pH & $6.81^{\mathbf{a}}$ & $6.79^{\mathbf{a}}$ \\
\hline TVBN (mg/100g flesh) & $17.81^{\mathbf{b}}$ & $21.38^{\mathbf{a}}$ \\
\hline TBA (mg/kg) & $1.84^{\mathbf{a}}$ & $1.02^{\mathbf{b}}$ \\
\hline
\end{tabular}

Means with different superscript in the same raw are significantly different $(\mathrm{P}<0.05)$

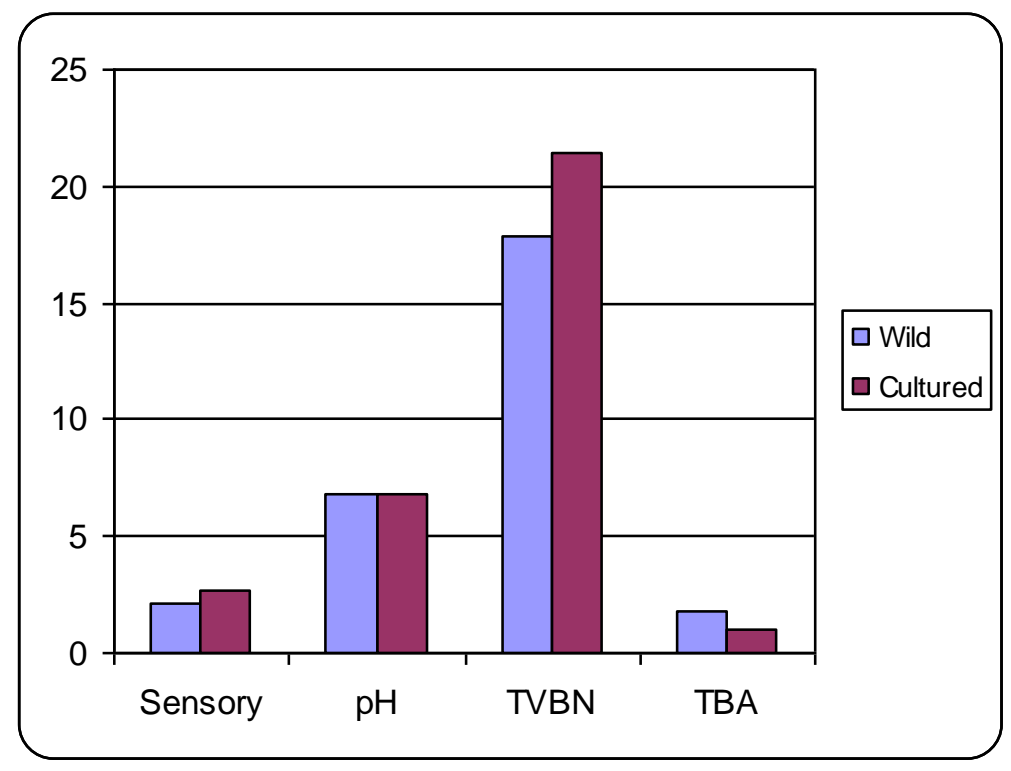

Figure 1: Comparison between mean values of sensory and chemical quality parameters of wild and cultured Nile Tilapia 
Table 7: Chemical composition $(\%)$ parameters of wild Nile Tilapia $(n=50)$

\begin{tabular}{|c|c|c|c|c|}
\hline Parameters & Min & $\operatorname{Max}$ & Mean & $\pm \mathrm{SE}$ \\
\hline Moisture & 77.86 & 82.15 & 79.63 & \pm 0.13 \\
\hline Protein & 14.78 & 19.41 & 17.5 & \pm 0.12 \\
\hline Fat & 0.41 & 2.16 & 1.2 & \pm 0.05 \\
\hline Ash & 0.85 & 1.22 & 1.04 & \pm 0.01 \\
\hline Carbohydrate & 0.04 & 1.62 & 0.63 & \pm 0.06 \\
\hline
\end{tabular}

Table 8: Chemical composition $(\%)$ parameters of cultured Nile Tilapia $(n=49)$

\begin{tabular}{|c|c|c|c|c|}
\hline Parameter & Min & $\operatorname{Max}$ & Mean & \pm SE \\
\hline Moisture & 73.74 & 80.38 & 77.17 & \pm 0.22 \\
\hline Protein & 15.27 & 19.63 & 17.91 & \pm 0.15 \\
\hline Fat & 1.2 & 4.9 & 2.82 & \pm 0.13 \\
\hline Ash & 0.89 & 1.45 & 1.17 & \pm 0.02 \\
\hline Carbohydrate & 0.1 & 1.94 & 0.94 & \pm 0.07 \\
\hline
\end{tabular}

Table 9: Mean values of chemical composition (\%) parameters of wild and cultured Nile Tilapia

\begin{tabular}{lcc}
\multicolumn{1}{c}{ Parameters } & Wild & Cultured \\
\hline Moisture & $79.63^{\mathbf{a}}$ & $77.17^{\mathbf{b}}$ \\
\hline Protein & $17.5^{\mathbf{b}}$ & $17.91^{\mathbf{a}}$ \\
\hline Fat & $1.2^{\mathbf{b}}$ & $2.82^{\mathbf{a}}$ \\
\hline Ash & $1.04^{\mathbf{b}}$ & $1.17^{\mathbf{a}}$ \\
\hline Carbohydrate & $0.63^{\mathbf{b}}$ & $0.94^{\mathbf{a}}$ \\
\hline
\end{tabular}

Means with different superscript in the same raw are significantly different $(\mathrm{P}<0.05)$

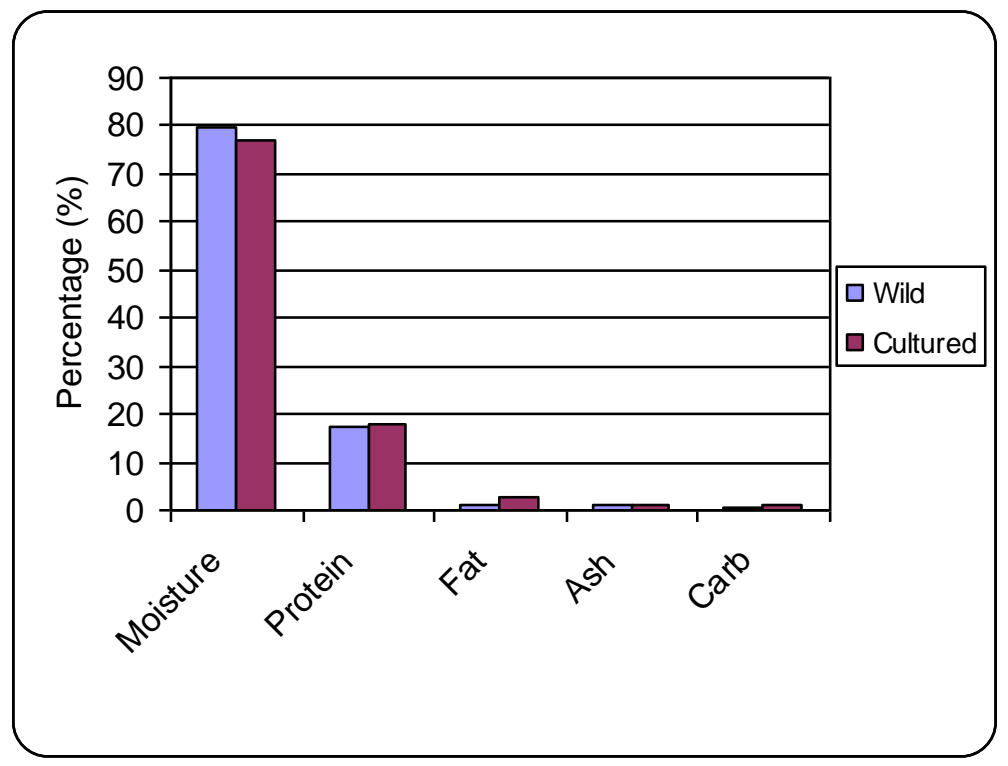

Figure 2: Comparison between mean values of chemical composition (\%) of wild and cultured Nile Tilapia 
Table 10: Energy value (Kcal/100g flesh) of wild and cultured Nile Tilapia

\begin{tabular}{lllll}
\hline \multicolumn{1}{c}{ Type of fish } & Min & Max & Mean & \pm SE \\
\hline Wild $(\mathbf{n = 5 0})$ & 73.75 & 92.51 & $83.29^{\mathbf{b}}$ & \pm 0.06 \\
\hline Cultured $(\mathbf{n = 4 9})$ & 85.2 & 124.77 & $100.73^{\mathbf{a}}$ & \pm 1.44 \\
\hline
\end{tabular}

Means with different superscript in the same column are significantly different $(\mathrm{P}<0.05)$

\section{DISCUSSION}

The quality of any kind of fresh fish includes different parameters such as organoleptic examination, chemical parameters such as $\mathrm{pH}$ value, TVB and microbial load. The increased production of Nile tilapia has raised concerns over the quality of the cultured fish in comparison with the wild fish.

Results of sensory evaluation showed that all of the examined cultured and wild fish samples were organoleptically accepted. The mean value of sensory scores was significantly $(\mathrm{P}<0.05)$ higher in cultured tilapia (2.72 \pm 0.02$)$ than in wild one $(2.17 \pm 0.03)$. Most of the samples $(61.22 \%)$ had a sensory grade "E" for cultured fish, while most of the wild fish samples $(82 \%)$ had a grade "A". Cultured fish usually kept chilled in crushed ice directly after catching that help to keep their fresh state, and allow slow occurring and long lasting rigors, which may raise the fish sensory scores. The obtained results for wild tilapia are in line with those recorded by Ammar (2001) who stated that all the examined tilapia samples were organoleptically accepted with a mean score value of $2.1 \pm 0.09$ and that most of the examined samples $(68 \%)$ were of grade "A". Haard (1992) mentioned that wild fish were found to have better texture than cultured one of the same species, which in part disagreed with the present findings.

Knowledge about the $\mathrm{pH}$ of fish meat may give valuable information about its condition. The recorded $\mathrm{pH}$ values of cultured tilapia was lower than that of wild one, with no significant difference $(\mathrm{P}>0.05)$ between their mean values. This was partially agreed with those found by Baz et al. (2014) who recorded lower $\mathrm{pH}$ for cultured than for wild tilapia but with significant difference between them. The current $\mathrm{pH}$ mean value was higher than that recorded by the previous authors for cultured $(5.84 \pm 0.02)$ and wild $(5.92 \pm 0.23)$ tilapia. Likewise, Ammar (2001) and El Said et al. (2011) recorded lower $\mathrm{pH}$ mean value $(6.64 \pm 0.06$ and $6.4 \pm 0.4$, respectively) for wild tilapia. The lower $\mathrm{pH}$ values in cultured tilapia may be attributed to the higher carbohydrate (glycogen) content of its flesh $(0.94 \%)$ in comparison with that of wild tilapia flesh $(0.63 \%)$. The ultimate $\mathrm{pH}$ of fish flesh after death is related to amount of glycogen available at death. The more glycogen present, the lower the $\mathrm{pH}$ value (Hall, 1992).
Total volatile base (TVB) mean value $(\mathrm{mg} / 100 \mathrm{~g}$ flesh) was higher, while thiobarbituric acid (TBA) mean value $(\mathrm{mg} / \mathrm{kg})$ was lower in cultured than in wild tilapia with a significant difference $(\mathrm{P}<0.05)$ between them. This disagreed with the findings of Baz et al. (2014) who reported lower TVB and higher TBA mean values in cultured than in wild tilapia, with a significant difference only in case of TVB. In general, the authors reported mean values for TVB $(7.92 \pm 0.49$ and $10.39 \pm 0.05)$ and for TBA $(0.26 \pm 0.01$ and $0.22 \pm 0.02$ ) in cultured and wild tilapia, respectively, which is lower than the present results. As well lower TVB mean values, $11.71 \pm 1.2$ and $12.32 \pm 1.6$, were recorded for wild tilapia by Ammar (2001) and El Said et al. (2011), respectively. In the same line, Hassan (2011) noted lower TVB $(12.3 \pm 0.4)$ and TBA $(0.29 \pm 0.04)$ values for fresh fish samples.

According to the Egyptian standards for chilled fish, the TVB value must not exceed $30 \mathrm{mg} / 100 \mathrm{~g}$ flesh and TBA value must not exceed $4.5 \mathrm{mg}$ malonaldehyde/kg fish flesh (EOSQC, 2005). It is clear from the obtained results that all the examined cultured and wild samples were not exceeding the previous limits except for only $2(4 \%)$ samples of wild tilapia which had TBA values above $4.5 \mathrm{mg}$ (4.87 and $5.43 \mathrm{mg}$ ), despite they are still organoleptically accepted (both have score "B"). These results partially in comply with those recorded by Baz et al. (2014) for cultured and wild tilapia and by Ammar (2001) and El Said et al. (2011) for wild tilapia samples.

The results of bacterial quality parameters revealed that the values of coliform, fecal coliform, E. coli, and Clostridium perfringens count (MPN/g) were higher in cultured than in wild tilapia samples. In cultured fish 83.67, 40.82, 2.02 and $6.12 \%$ of the examined samples were contaminated with the previously mentioned microorganisms, respectively. Meanwhile, in wild fish 88 and $34 \%$ of the examined samples were contaminated with coliform and fecal coliform, respectively, and none of the samples were contaminated by E. coli or Clostridium perfringens.

Of the positive (41) cultured fish samples, 7 (17.07\%) were have coliform count of 1100 and only 1 (2.44\%) was have a count $>1100 \mathrm{MPN} / \mathrm{g}$. For wild fish, only 1 (2.27\%) sample of the positives (44) was have a count of 1100 and none found to have count $>1100$ $\mathrm{MPN} / \mathrm{g}$. For fecal coliform, only 1 (5\%) of the 
positive (20) cultured fish sample show a count of 1100, while none of the wild samples show such count. Clostridium perfringens and E.coli were recorded at low counts in the cultured tilapia samples only.

El Said et al. (2011) recorded coliform count ranged from $0.5 \times 10^{3}$ to $3.5 \times 10^{3}$ with a mean value of $1.69 \times 10^{3} \pm 0.15 \times 10^{3} \mathrm{cfu} / \mathrm{g}$ in all the examined wild tilapia samples, which was higher than the current findings. As well, Ammar (2001) detected higher incidence $(80 \%)$ of anaerobes and a count ranged from $1 \times 10$ to $1 \times 10^{5}$ with a mean value of $4.5 \times 10^{3} \pm 3.9 \times 10^{3} \mathrm{cfu} / \mathrm{g}$ in the wild tilapia samples.

The Egyptian standards (EOSQC, 2005) for chilled fish stated that coliforms count must not exceed $100 \mathrm{cfu} / \mathrm{g}$. Regarding that, 26.53 and $10 \%$ of the examined cultured and wild tilapia samples, respectively, were found exceeded this limit. This result was lower than that recorded by El Said et al. (2011) for wild tilapia, who found coliforms in all the examined samples.

High incidence of coliforms (83.67\%), fecal coliforms $(40.82 \%)$ and the presence of E. coli and Clostridium perfringens in some of the cultured fish samples can suggest fecal contamination either from the rearing environment (use of drain water or organic matter of human origin for fish rearing) or during handling which may suppose public health hazard. Gram and Huss (2000) stated that the high coliforms count in the examined samples was indicative of massive contamination with deteriorative bacteria which mostly lead to flavor deterioration of the fish. On the other hand, the low coliform count in wild sample may be suspected because of their free living and natural feeding, despite may indicate poor hygiene.

For proximate chemical composition, the data presented in Table (9) and Figure (2) revealed that cultured tilapia showed significantly $(\mathrm{P}<0.05)$ lower moisture, but higher protein, fat, ash and carbohydrate contents in comparison with their wild counterparts. Baz et al. (2014) declared that the mean value of moisture, fat and ash percentages of the cultured tilapia fish had a higher level than that of wild fish, while protein percentage is lower, which was in partial agreement with the present findings. The authors attributed that to feeding of cultured fish on a ration contain a high level of fat and ash, beside the long period of culturing till marketing.

Sulieman and James (2011) recorded non-significant difference $(\mathrm{P}>0.05)$ for moisture and ash content between wild and cultured tilapia, while protein and fat contents were significantly $(\mathrm{P}<0.05)$ higher in wild fish than in cultured one, which in contrary with the present observations. Likewise, Muchiri and Nanua (2006) reported that nutritional composition of cultured Nile tilapia was not significantly vary from the wild catch fish except for the lipid content.

FAO (2001) reported that total ash rarely exceeds 1-2 per cent of the edible portion of fish, which is in line with the current findings. Nearly similar moisture $(79.43 \%)$, lower lipid $(0.42 \%)$ and protein $(15.77 \%)$ and slightly higher ash $(1.42 \%)$ were detected for wild tilapia flesh by de Silva and Rangoda (1979). On the other hand Wimalasena and Jayasuriya (1996) observed lower moisture (78.3 \pm 1.3$)$, higher lipid $(2.3 \pm 0.7)$, and nearly similar protein $(17.8 \pm 0.7)$ and ash $(1.1 \pm 0.1)$ contents for wild tilapia flesh

Mohammed (2013) reported nearly similar moisture and fat contents for wild tilapia $(79.27 \pm 0.22$ and $1.17 \pm 0.34$, respectively), but lower protein $(16.74 \pm 0.3)$ and higher ash $(1.45 \pm 0.45)$. On the other hand, lower moisture, higher protein and fat and nearly similar ash values were recorded for wild tilapia by Adam et al. (2015).

Celik (2008); Grigorakis et al. (2002) and Gonzalez et al. (2006) found in other fish species that the wild fish were have a higher protein content than their cultured counterparts attributing this to their significantly lower moisture content which is in opposite with the current findings. Yeganeh et al. (2012) and Periago et al. (2005) stated that muscle fat levels of the cultured and wild fish showed no significant differences $(\mathrm{P}>0.05)$, a matter which disagreed with the present results. On the contrary, Alasalvar et al. (2002); Olsson et al. (2003); Rodriguez et al. (2004); Gonzalez et al. (2006) and Mnari et al. (2007) showed a higher muscle fat content in the cultured than in the wild counterparts which is in line with the present data.

Higher lipid content in cultured fish is expected when compared to their wild counterparts due to a variety of factors including availability and type of food, dietary ingredients (commercial diets are usually high in fat content and also include dietary carbohydrate), higher energy consumption in cultured fish when compared to wild fish, and possible periods of starvation encountered by wild fish (Haard, 1992; Grigorakis et al., 2002). It is worth to mention that Grigorakis et al. (2002) stated that fatty acid in the feed accumulated largely unchanged in the lipid of marine fish because of their reduced capacity for the chain elongation and desaturation.

The current results for carbohydrate either for cultured or wild tilapia were in line with that stated by FAO (2001) "the amount of carbohydrate in white muscle is generally too small usually less than 1 per cent". De Silva and Rangoda (1979) and Mohammed (2013) recorded higher carbohydrate content for wild tilapia, while Henin (2016) recorded a higher content for cultured tilapia. On contrary, Wimalasena and Jayasuriya (1996) detected no carbohydrate in the flesh of wild tilapia. 
The results of the gross energy content (Kcal/100g flesh) revealed significantly lower value for wild tilapia than for cultured one. This may be mainly attributed to the higher fat content of the cultured tilapia flesh. Mohammed (2013) reported nearly similar energy value $(84.69 \pm 3.24)$ for wild tilapia, while Henin (2016) recorded lower value $(91.41 \pm 1.43)$ for cultured tilapia.

From the previous data it could be concluded that, from the quality point of view wild Nile tilapia is better than the cultured one. Despite cultured fish seems higher in its nutritive value especially protein content; the high fat content of its flesh, which may be saturated (represents an area deserved of future research), could make it unsuitable diet for consumers especially those who are at risk of cardiovascular diseases. Moreover the high microbial load (coliforms and fecal coliforms) of cultured tilapia may signal public health hazard. As consumers expect cultured fish to be equivalent or superior to the wild one, therefore more control is required on different stages of the rearing, feeding and processing steps to deliver to consumers a designer tilapia fish with preferred quality and nutritional compositions.

\section{REFERENCES}

Adam, H.M.Y.; Ahmed, A.M.M.; Ibrahim, A.M.A. and Yousif, F.M. (2015): Comparative study of the body weight characteristics and effect of drying on chemical composition of three Nile fish species (Oreochromis Niloticus, Labeo Niloticus and Clarias Spp.). Online Journal of Animal and Feed Research, 5 (6): 175-180.

Alasalvar, C.; Taylor, K.D.A.; Zubcov, E.; Shahidi, F. and Alexis, M. (2002): Differentiation of cultured and wild sea bass (Dicentrarchus labrax): total lipid content, fatty acid and trace mineral composition. Food Chemistry, 79 (2): 145-150.

Amer, A.A.; Ibrahim, H.A. and Mohamed, Heba, R. (2012): Enteropathogen of some freshwater fishes. Alex. J. Vet. Sci., 37 (1): 49-52.

Ammar, M.A.M. (2001): Sanitary assessment of some common fresh water fish in Assiut. M. V. Sc. Thesis, Fac. Vet. Med. Assiut Univ. Egypt.

AOAC "Association of Official Analytical Chemists" (1980): Official Methods of Analysis of the Association of Official Analytical Chemists. $13^{\text {th }}$ Ed. Horwitz, W. (edit). Washington, DC.

AOAC (2000): Official Methods of Analysis of the Association of Official Analytical Chemists. $17^{\text {th }}$ Ed., AOAC International, Gaithersburg. MD.

Ashraf, M.; Ahmad, V.; Ahmad, I.; Ahmad, S.; Arshad, S.; Muhammad, A.S.S. and Nasim, F. (2011): Acetylcholinesterase and NADH oxidase inhibitory activity of some medicinal plants. J. Med. Plants Res., 5 (10): 2086-2089.
Baz, G.M.B.; Salama, Hanaa, F.; El-Fiky, Salwa, A.H. and Saleh, Omima, A. (2014): Comparative study on spoilage markers and chemical composition of cultureded and wild Oreochromis niloticus. Journal of the Arabian aquaculture Society, 9 (1): 171-182.

Beerens, H.; Romond, Ch.; Lepage, C. and Criquelion, J. (1980): A liquid medium for the enumeration of Clostridium perfringens in foods and faeces.

Boari, C.A.; Pereira, G.I.; Valeriano, C.; Silva, B.C.; De Morais, V.M.; Figueiredo, H.C.P. and Piccoli, R.H. (2008): Bacterial ecology of tilapia fresh fillets and some factors that can influence their microbial quality. Ciênc. Tecnol. Aliment. 28:863-867.

Brock, M.J.M.; Mossel, D.A.A. and Mol, H. Space (1984): Microbiological quality of retail fresh fish fillets in Netherlands. International $J$. Food Microbiol., 1: 53-61.

Bryan, F.L. (1980): Epidemiology of foodborne diseases transmitted by fish, shellfish and marine crustaceans in the United States, 19701978. J. Food Prot., 43 (11): 859-876.

Buege, J.A. and Aust, S.D. (1978): Microsomal lipid peroxidation. Methods in Enzymology, 52: 302-310

Celik, M. (2008): Seasonal changes in the proximate chemical compositions and fatty acids of chub mackerel (Scomber japonicus) and horse mackerel (Trachurus trachurus) from the north eastern Mediterranean Sea. International Journal of Food Science and Technology, 43: 933-938

Cox, D.H. and Karahadian, C. (1998): Evaluation of microbial counts, nucleotide degradation, and sensory attributes of cultured and wild yellow perch (Perca falvescens) during refrigerated storage. Journal of Aquatic and Food Production Technology, 7 (1): 5-26.

De Silva, S.S. and Rangoda, M. (1979): Some chemical characteristics of fresh and salt dried Tilapia mossambica petess. Journal of National Science Council of Sri Lanka, 7 (1): 19-27.

Delwiche, J.F. and Liggett, R.E. (2004): Sensory preference and discrimination of wild-caught and cultured yellow perch (Perca flavescens). J Food Sci, 69 (4): 144-147.

Dergal, N.B.; Abi-Ayad, S.M.E.A.; Degand, G.1.; Douny, C.; Brose, F.1.; Daube, G.; Rodrigues, A. and Scippo, M.L. (2013): Microbial, biochemical and sensorial quality assessment of Algerian cultureded tilapia (Oreochromis niloticus) stored at 4 and $30^{\circ} \mathrm{C}$. African Journal of Food Science, 7(12): 498-507.

El Said, Ola, M.; Samaha, I.A. and Ibrahim, H.A. (2011): Quality assessment of some fresh water fish. Alex J. Vet. Sci., 34 (1): 135-142.

EOSQC "Egyptian Organization for Standardization and Quality Control" (2005): ES 3494 for chilled fish. 
Etzel, V.; Meyer, C.; Ballin, U. and Krause, R. (1998): Investigation for the evaluation of quality of Nile Perch after arriving at German Wholesars. FSTA, 30 (12): 226.

FAO "Food and Agriculture Organization" (1995): Quality and Quality Changes in Fresh Fish. Huss, H. H. (edit), FAO Fisheries Technical Paper No. 348.

FAO (2001): The composition of fish. Murray, J and Burt, J. R. (edit), Torry Advisory Note No.38, Online

http://www.fao.org/wairdocs/tan/x5916e/x591 6e00.htm. pp 1-80.

$F A O$ (2012): The state of world fisheries and aquaculture 2012. Rome. p. 209.

GAFRD "General Authority for Fish Resources Development" (2010): Fishery. Annual Report, Cairo, Egypt.

Gonzalez, S.; Flick, G.J.; O'Keefe, S.F.; Duncan, S.E.; McLean, E. and S.R. Craig, S. R. (2006): Composition of cultureded and wild yellow perch (Perca flavescens). Journal of Food Composition and Analysis, 19: 720-726.

Gram, L. and Huss, H.H. (2000): Microbiological spoilage of fish and fish products. International J. Food Microbiol., 33 (1): 121137.

Grigorakis, K.; Alexis, M.N.; Taylor, K.D.A. and Hole, M. (2002): Comparison of wild and cultured gilthead sea bream (Sparus aurata); composition, appearance and seasonal variations. Inter J. Food Science and Techno, 37: 477-484.

Grigorakis, K.; Taylor, K.D.A. and Alexis, M.N. (2003): Organoleptic and volatile aroma compounds comparison of wild and cultured gilthead sea bream (Sparus aurata): sensory differences and possible chemical basis. Aquacul, 225(1-4): 109-119.

Haard, N.F. (1992): Control of chemical composition and food quality attributes of cultured fish. Food Research International, 25: 289-307.

Hall, G. M. (1992): Fish Processing Technology ${ }^{1}$ st Ed.; Chapman and Hall, USA.

Hassan, Azza, E.A and EL-Shahat A.F. (2011): Chemical evaluation of some fresh and frozen fish. Assiut Vet Med J., 57 (130): 97-106.

Henin, Martha, H.A. (2016): Nutritive value of cultured fish. M. V. Sc. Thesis. Fac. Vet Med. Assiut Univ. Egypt.

Hoyland, D.V. and Taylor, A.J. (1991): A review of the methodology of the 2-thiobarbituric acid test. Food Chemistry, 40 (3):271-291.

Huss, H.H. (1988): Fresh fish quality and quality Changes. FAO Fisheries No. 29, Italy Pp 132.

Izquierdo, M.S.; Obach, A.; Arantzamendi, L.; Montero, D.; Robaina, L. and Rosenlund, G. (2003): Dietary lipid sources for sea bream and sea bass: Growth performance, tissue composition and flesh quality. Aquaculture nutrition, 9: 397-407.
Jankowska, B.; Zakes, Z.; Zmijewski, T. and Szczepkowski, M. (2003): A comparison of selected quality features of the tissue and slaughter yield of wild and cultivated pikeperch Sander lucioperca (L.). Europ Food Res Tech, 217 (5): 401-405.

Jurgens, M.H. and Bregendahl, K. (2007): Animal feeding and nutrition. $10^{\text {th }} \mathrm{Ed}$. Kendall/Hunt Publishing Company, Iowa, USA.

Lie, O. (2001): Flesh quality - the role of nutrition. Aquacultural Research, 32: 341-348.

Lyhs, U.; Hatakka, M.; Maki-Petays, N.; Hyytia, E. and Korkeala, H. (1998): Microbiological quality of Finnish vacuum-packaged fishery products at retail level. Archiv fur Lebensmittelhygiene, 49 (6): 146-150.

Merrill, A.L. and Watt, B.K. (1973): Energy value of foods, basis and derivation. Agriculture Handbook No. 74.Washington, DC, Unites States Depart Agricul.

Mnari, A.; Boundel, I.; Chraief, I.; Hammami M.; Romdhane, M.S.; El Cafsi, M. and Chaouch, A. (2007): Fatty acids in muscle and liver of Tunisian wild and cultureded gilthead sea bream, Sparus aurata. Food Chemistry, 100: 1393-1397.

Mohammed, Fatma, A. (2013): Study on nutritional value of some Nile fish. Ph.D. Thesis. Fac. Vet. Med. Assiut Univ. Egypt.

Muchiri, M. and Nanua, J. (2006): A comparison of nutritional value of cultureded and wild Nile tilapia (O. niloticus). Aqua 2006: May 9 - 13, Florence, Italy.

National Academy of Science (1985): An evaluation of the role of microbiological criteria for foods and food ingredients. National Academy Press. Washington, D.C.

Nettleton, J.A. and Exler, J. (1992): Nutrients in wild and cultureded shellfish. Journal of Food Sciences, 57 (2): 257-260.

Noseda, B.; Ragaert, P.; Pauwels, D.; Anthierens, T.; Van Langenhove, H.; Dewulf, $J$. and Devlieghere, F. (2010): Validation of selective ion flow tube mass spectrometry for fast quantification of volatile bases produced on Atlantic cod (Gadus morhua). J. Agric. Food Chem., 58 (9):5213-9.

Olsson, G.B.; Olsen, R.L.; Carlehog, M. and Ofstad, $R$. (2003): Seasonal variations in chemical and sensory characteristics of cultureded and wild Atlantic halibut (Hippoglossus hippoglossus). Aquaculture, 217: 191-205.

Ozogul, Y.; Boga, K.E.; Tokur, B. and Ozogul, F. (2011): Changes in biochemical, sensory and microbiological quality indices of common sole (Solea solea) from the Mediterranean sea during ice storage. Turk. J. Fish. Aquat. Sci. 11: $243-251$.

Pearson, D. (1976): The analysis of Foods. $7^{\text {th }}$ Ed. Longman Inc. USA.

Periago, M.J.; Ayala, M.D.; Lopez-Albors, O.; Abdel, I.; Martinez, C.; Garcia-Alcazar, A.; Ros, G. 
and Gil, F. (2005): Muscle cellularity and flesh quality of wild and cultureded sea bass, Dicentrachus labrax L. Aquaculture, 249: 175188.

Raharjo, J. and Sofos, J.N. (1993): Methodology for measuring malonaldehyde as a product of lipid peroxidation in muscle tissue. A review. Meat science, 35: 145-169

Rasmussen, R.S. (2001): Quality of cultureded salmonids with emphasis on proximate composition, yield, and sensory characteristics. Aquaculture Research 32: 767786.

Rodriguez, C.; Acosta, C.; Badia, P.; Cejas, J.R.; Satamaria, F.J. and Lorenzo, A. (2004): Assessment of lipid and essential fatty acid requirements of black sea bream (Spondyliosoma cantharus) by comparison of lipid composition in muscle and liver of wild and captive adult fish. Comp Biochem Physiol B, 139: 619-629.

Sulieman, H.M.A. and James, G.K. (2011): A comparative studies on the chemical and physical attributes of wild cultureded Nile
Tilapia (Orechromis niloticus). Online Journal of Animal Feed Research, 1 (6): 407-411.

Wimalasena, S. and Jayasuriya, M.N.S. (1996): Nutrient analysis of some fresh water fish. J. Natn. Sci. Coun. Sri Lanka, 24 (1): 21-26.

Yao, Y.; Zhang, P.; Chen, Y.H.; Tian, C.E.; Liu, W.F.; Wang, Z.C. and Shen, S.B. (2009): A spectral analysis method for total volatile base nitrogen. Guang Pu Xue Yu Guang Pu Fen Xi. 2009 Aug; 29 (8):2196-8.

Yarnpakdee, S.; Benjakul, S.; Nalinanon, S. and Kristinsson, H.G. (2012): Lipid oxidation and fishy odour development in protein hydrolysate from Nile tilapia (Oreochromis niloticus) muscle as affected by freshness and antioxidants. Food Chem., 132:1781-1788.

Yeganeh, S.; Shabanpour, B.; Hosseini, H.; Imanpour, M.R. and Shabani, A. (2012): Composition of cultureded and wild common carp (Cyprinus carpio): Seasonal variations in chemical composition and fatty acid profile. Czech Journal of Food Sciences, 30 (6): 503511.

\section{دلائل الجودة و القيمة الغذائية لأسماك البلطي المستزرعة والنيلية المتاولة باسواق مدينة أسيوط ، مصر شريف محد سبي عبل الله ، هشام عبل المعز أحدد إسعاعيل}

Email: Sherief74@yahoo.com_Assiut University web-site: $\underline{\text { www.aun.edu.eg }}$

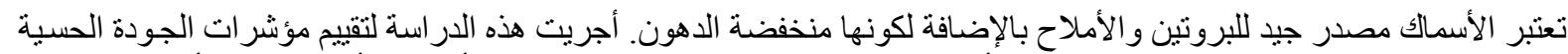

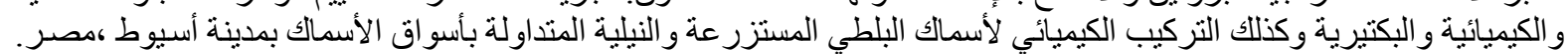

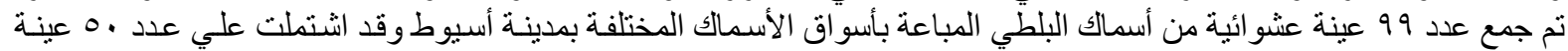

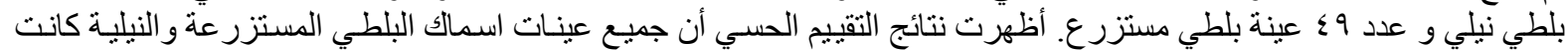

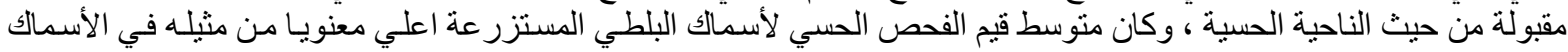

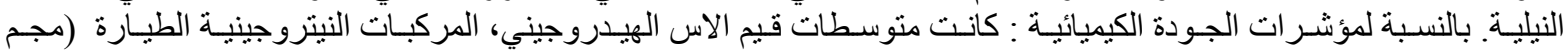

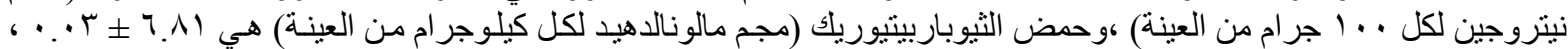

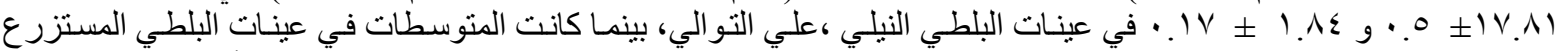

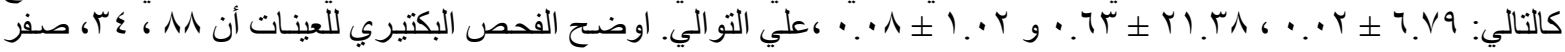

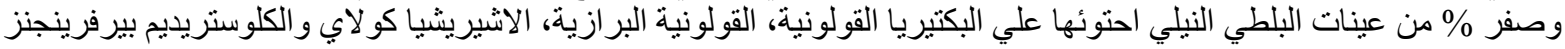

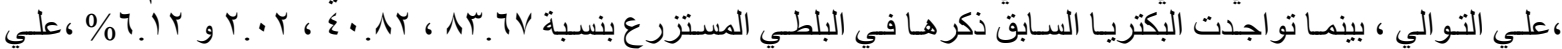

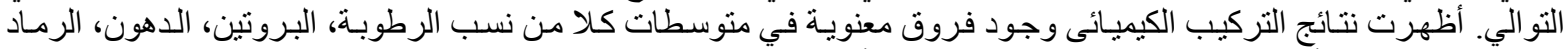

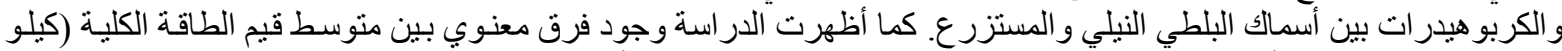

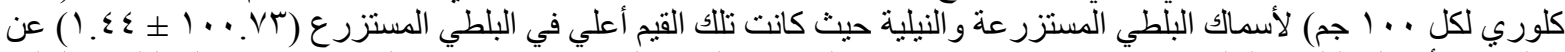

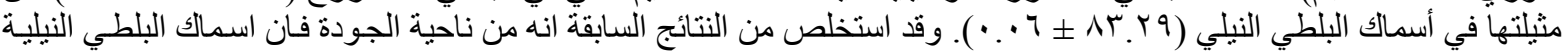

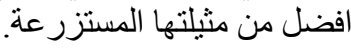

الكلمات الكاثفة: اسماك البلطي، نيلي، مستزرع، الجودة، التركيب الكيميائي، حسي، كيميائي، بكتيري. 